\title{
HYPODERMOCLYSIS FOR CORRECTION OF HYPEROSMOLAR DEHYDRATION AND SEVERE ELECTROLYTE DISTURBANCES: A CASE REPORT
}

\author{
Hipodermóclise para correção de desidratação \\ hiperosmolar e distúrbios eletrolíticos graves: relato de caso \\ Marco Túlio Gualberto Cintraa (i)
}

The treatment of dehydration and severe electrolyte disturbances using hypodermoclysis is usually contraindicated, $\vdash \quad$ but the level of evidence for its recommendation is based on expert opinion. This case report describes an older $\varangle$ patient receiving palliative care who developed hyperosmolar dehydration with severe hypernatremia, acute kidney $₫$ injury, and hyperkalemia. She was treated with hypodermoclysis using a hypotonic solution, which led to complete resolution of the condition. In conclusion, further studies on the use of hypodermoclysis for the treatment of severe hydroelectrolytic disorders are needed.

KEYWORDS: hypodermoclysis; hypernatremia; hyperkalemia; acute kidney injury; palliative care; case reports; dementia.

O tratamento de desidratação e distúrbios eletrolíticos graves é contraindicado por meio de hipodermóclise, mas o nível de evidência da recomendação se baseia na opinião de especialistas. Descreve-se caso clínico de paciente com idade avançada, com indicação de cuidados paliativos, que evoluiu com desidratação hiperosmolar com hipernatremia grave, injúria renal aguda e hipercalemia. Tratou-se a paciente com solução hipotônica por meio da técnica de hipodermóclise, com resolução completa do quadro. Conclui-se que há necessidade de mais estudos sobre o uso da hipodermóclise para o tratamento de distúrbios hidroeletrolíticos graves.

PALAVRAS-CHAVE: hipodermóclise; hipernatremia; hiperpotassemia; lesão renal aguda; cuidado paliativo; relatos de casos; demência.

aDepartment of Clinical Medicine, School of Medicine, Universidade Federal de Minas Gerais - Belo Horizonte (MG), Brazil.

Correspondence data

Marco Túlio Gualberto Cintra - Departamento de Clínica Médica, Faculdade de Medicina, Universidade Federal de Minas Gerais - Avenida Professor Alfredo Balena, 190, sala 246 - Santa Efigênia - CEP: 30130-100 - Belo Horizonte (MG), Brasil. Email: marcotuliocintra@gmail.com Received on: 1/13/2020. Accepted on: 2/26/2020

DOI: 10.5327/Z2447-212320202000003

(C) 2020 Sociedade Brasileira de Geriatria e Gerontologia This is an open access article distributed under the terms of the Creative Commons license. 
Hypodermoclysis is a route of administration of drugs and fluids via subcutaneous tissue. Absorption occurs in blood and lymph capillaries in the hypodermis. This route is widely used in palliative care in patients who are unable to use the oral route and/or venous access. It allows good control of uncomfortable symptoms, such as pain and nausea, and maintains adequate hydration in the final stage of life. Hypodermoclysis has the advantages of being more comfortable and less costly than the venous route, with less risk of congestion, electrolyte disturbances, and infections. However, there are restrictions such as absorption of certain drugs and limited volume of fluids to be administered. ${ }^{1,2}$

Hypodermoclysis is not recommended by consensus statements for cases of severe hydroelectrolytic disorders, shock, and those requiring rapid fluid infusion. ${ }^{2-4} \mathrm{Next}$, we describe a clinical case in which hypodermoclysis has surprisingly reversed severe dehydration associated with hypernatremia, hyperkalemia, and acute kidney injury in a nearly centenarian patient receiving palliative care.

\section{CASE REPORT}

A 99-year-old white woman had advanced Alzheimer's disease classified as stage $7 \mathrm{~d}$ in the Functional Assessment Screening Tool (FAST). ${ }^{5}$ Her estimated survival time was less than 6 months according to a risk score proposed by Mitchell. ${ }^{6}$ The indication for palliative care at home had been previously agreed with family members.

The patient had idiopathic interstitial lung disease and stage 4 chronic kidney disease. She used escitalopram $(5 \mathrm{mg}$ once daily), mirtazapine (30 $\mathrm{mg}$ once daily), and quetiapine ( $37.5 \mathrm{mg}$ once daily) to control behavioral and psychological symptoms of dementia (BPSD), as well as combined fluticasone and salmeterol (250/25 mcg twice daily) because of previous episodes of bronchospasm. Liver and thyroid function tests, complete blood count, and serum electrolytes performed every 6 months showed no abnormalities.

In August 2018, the patient had severe and progressive prostration for 7 days combined with 3 days of anuria and anorexia, when the health care team was called. On physical examination, there were no changes in mucosal color and no edema. Capillary refill time was 2 seconds; the patient opened her eyes to painful stimuli, uttered incomprehensible sounds, and identified the site of painful stimuli. Lung auscultation revealed diffuse Velcro crackles, oxygen saturation of $92 \%$, and a respiratory rate of 24 breaths per minute. Cardiovascular and abdominal examinations showed no abnormalities. Also, heart rate was $82 \mathrm{bpm}$, blood pressure was $130 \times 70 \mathrm{~mm} \mathrm{Hg}$, and capillary blood glucose was $78 \mathrm{mg} / \mathrm{dL}$. The oral diet and all prescribed medications were suspended, except for inhalation, and urgent laboratory tests were ordered and performed at home (abnormal results are described in Table 1).

As the results suggested severe hyperosmolar dehydration associated with severe hypernatremia, acute chronic kidney disease, and hyperkalemia, family members were informed about the imminence of death and the patient was cared for at home. There was no evidence of infection. Only hydration with $5 \%$ isotonic glucose solution (approximately 1,000 $\mathrm{mL}$ daily) was prescribed, using hypodermoclysis, puncture with butterfly needle, and simple macrodrip tubing. The initial purpose of hypodermoclysis puncture was exclusively to offer a hydration route to the patient in the final stage of life. Administration of opioids and/or sedatives was unnecessary because of decreased level of consciousness.

After 24 hours of hydration, the patient showed improved level of consciousness and, after 72 hours, started having some diuresis. Because of the improved level of consciousness, soft foods and thickened liquids were allowed as of the third day of treatment.

After a week of treatment, the patient was at a level of consciousness equal to baseline, allowing the use of a bland diet and suspension of the thickener. New laboratory tests showed a significant improvement in electrolyte disturbances and renal function (Table 1). The tests were repeated after 14 days of the introduction of hydration, confirming the improvement and suspending subcutaneous hydration, and after 30 days of the suspension of hydration (Table 1). During the 14 days of infusion, the hypodermoclysis site was changed twice (anterolateral right thigh, anterolateral left thigh, and abdomen, respectively). Medications for BPSD control were gradually reintroduced as of the 14th day of treatment.

Table 1 Laboratory test results.

\begin{tabular}{l|c|c|c|c|c} 
& $8 / 16 / 2018$ & $8 / 22 / 2018$ & $8 / 29 / 2018$ & $9 / 21 / 2018$ & Reference values \\
\hline Creatinine & 3.87 & 3.07 & 2.08 & 1.78 & $0.7-1.2 \mathrm{mg} / \mathrm{dL}$ \\
\hline Urea & 276 & 201 & 108 & 71 & $15-45 \mathrm{mg} / \mathrm{dL}$ \\
\hline Sodium & 174 & 153 & 155 & 147 & $135-142 \mathrm{mmol} / \mathrm{L}$ \\
\hline Potassium & 6.7 & 5.1 & 5.1 & 4.8 & $3.5-5.2 \mathrm{mmol} / \mathrm{L}$ \\
\hline
\end{tabular}




\section{DISCUSSION}

This case report describes the administration of hypotonic solution by hypodermoclysis in a 99-year old patient receiving palliative care at home due to advanced dementia with acute kidney injury, severe hypernatremia, and hyperkalemia, which resulted in reversal of severe dehydration. To the best of the author's knowledge, no papers have reported on the correction of severe electrolyte disturbances by hypodermoclysis.

Dehydration is defined as a decline in total body water, whose etiology is related to water loss (hypertonic) or salt loss (hypotonic). ${ }^{7}$ Frail older adults are particularly at risk of developing electrolyte abnormalities, as well as those with respiratory diseases (insensible water loss)., ${ }^{7,8}$ Dehydration may be hyperosmolar, with free water loss, increased serum level of sodium, and increased urea-creatinine ratio. ${ }^{7}$ The treatment of hyperosmolar dehydration is based on administration of hypotonic fluids. ${ }^{7}$

Hypodermoclysis consists of the subcutaneous administration of fluids using the cell diffusion mechanism. The technique is less uncomfortable and less costly than the intravenous route, with recommendation for cases of mild-to-moderate dehydration due to severe dysphagia, dementia, malignant bowel obstruction, or excessive sleepiness in patients with indication for palliative care and/or impossibility of puncturing a peripheral vein. ${ }^{5}$ It also favors the practice of palliative care in a non-hospital setting. ${ }^{9}$

The literature shows that electrolyte disturbances are associated with higher mortality in patients with cancer referred to palliative care units. Alsirafy et al. ${ }^{10}$ demonstrated an in-hospital mortality rate of $68.2 \%$ and $46.2 \%$ in patients with hypernatremia and hyperkalemia, respectively. There was a shorter survival time among patients with hypernatremia. ${ }^{10}$
According to Elsayem et al., ${ }^{11}$ hypernatremia is associated with higher in-hospital mortality in multivariate analysis.

Treating dehydration and severe electrolyte disturbances with hypodermoclysis is usually not recommended. Some consensus statements even contraindicate the technique, but the level of evidence for the recommendation is based on expert opinion. ${ }^{2,12}$

The Medical Literature Analysis and Retrieval System Online (MEDLINE) database was searched on January 13,2020 using the health descriptors "Palliative care" AND "Hypernatremia," "Hospice and Palliative Care Nursing” AND "Hypernatremia,"“Palliative Medicine"AND"“Hypernatremia," "Palliative care"AND "Hyperkalemia," "Hospice and Palliative Care Nursing” AND "Hyperkalemia," "Palliative Medicine" AND” "Hyperkalemia," "Hypodermoclysis" AND "Acute Kidney Injury," "Hypodermoclysis” AND “Hypernatremia," and "Hypodermoclysis" AND "Hyperkalemia." No papers on correction of severe electrolyte disturbances using hypodermoclysis were found.

In conclusion, this case report highlights the need for clinical trials on the effectiveness of hypodermoclysis in the treatment of severe electrolyte disturbances, as well as in the treatment of severe dehydration in patients with indication for palliative care.

\section{CONFLICT OF INTERESTS}

The author has no conflict of interests to disclose.

\section{FUNDING}

None.

\section{REFERENCES}

1. Azevedo DL, editor. O uso da via subcutânea em geriatria e cuidados paliativos. $2^{\mathrm{a}}$ ed. Rio de Janeiro: SBGG, 2017.60 p.

2. Caccialanza R, Constans T, Cotogni P, Zaloga GP, Pontes-Arruda A. Subcutaneous Infusion of Fluids for Hydration or Nutrition: A Review. JPEN J Parenter Enteral Nutr. 2018;42(2):296-307. https://doi. org/10.1177/0148607116676593

3. Turner T, Cassano AM. Subcutaneous dextrose for rehydration of elderly patients--an evidence-based review. BMC Geriatr. 2004;4:2. https://doi.org/10.1186/1471-2318-4-2

4. Remington R, Hultman T. Hypodermoclysis to treat dehydration: a review of the evidence. J Am Geriatr Soc. 2007;55(12):2051-5. https:/l doi.org/10.1111/j.1532-5415.2007.01437.x

5. Reisberg B. Functional Assessment Staging (FAST). Psychopharmacol Bull. 1988;24(4):653-9.

6. Mitchell SL. Advanced Dementia. N Engl J Med. 2015;372:2533-40. https://doi.org/10.1056/NEJMcp1412652

7. Morley JE. Dehydration, hypernatremia, and hyponatremia. Clin Geriatric Med. 2015:31(3):389-99. https://doi.org/10.1016/j.cger.2015.04.007
8. Thomas DR, Cote TR, Lawhorne L, Levenson SA, Rubenstein LZ, Smith DA, et al. Understanding clinical dehydration and its treatment. J Am Med Dir Assoc. 2008;9(5):292-301. https://doi.org/10.1016/j. jamda.2008.03.006

9. Bruno VG. Hipodermóclise: revisão da literatura para auxiliar a prática clínica. Einstein. 2015;13(1):122-8. https://doi.org/10.1590/S167945082015RW2572

10. Alsirafy SA, Sroor M, Al-Shahri MZ. Predictive Impact of Electrolyte Abnormalities on the Admission Outcome and Survival of Palliative Care Cancer Referrals. J Palliat Med. 2009;12(2):177-80. https://doi. org/10.1089/jpm.2008.0200

11. Elsayem A, Mori M, Parsons HA, Munsell MF, Hui D, Delgado-Guay $\mathrm{MO}$, et al. Predictors of inpatients mortality in an acute palliative care unit at a comprehensive cancer center. Support Care Center. 2010;18(1):67-76. https://doi.org/10.1007/s00520-009-0631-5

12. Forbat L, Kunicki N, Chapman M, Lovell C. How and why are subcutaneous fluids administered in an advanced illness population: a systematic review. J Clin Nurs. 2017;26(9-10):1204-16. https://doi.org/10.1111/jocn.13683 